\title{
ANTI-ULCER ACTIVITY OF LEGUMINOSAE PLANTS
}

\author{
Noemi D. PAGUIGAN¹, Darryl Hannah B. CASTILLO² and \\ Christine L. CHICHIOCO-HERNANDEZ ${ }^{2}$
}

\begin{abstract}
Context - Ulcer is the most common gastrointestinal disturbance resulting from an inadequate gastric mucosal defense. Several drugs are available in the market to address the disease; however, these drugs are associated with unnecessary side effects. Objectives - Previous research have confirmed the efficacy of plant extracts for possible treatment of the disease. This research aims to evaluate the anti-ulcer properties of medicinal plants. Methods - Methanol extracts from the leaves of Intsia bijuga, Cynometra ramiflora, Tamarindus indica, Cassia javanica, Cassia fistula, Bauhini purpurea, Senna spectabilis, Senna siamea and Saraca thaipingensis were evaluated for their anti-ulcer activity using $\mathrm{HCl}$-ethanol as ulcerogen. Results - All extracts showed inhibitory activity with I. bijuga, T. indica, S. spectabilis and S. thaipingensis exhibiting more than $50 \%$ inhibition. S. thaipingensis showed the highest activity at $80 \%$. S. spectabilis and $S$. thaipingensis were partitioned further into hexane, ethyl acetate and aqueous fractions. The aqueous and ethyl acetate fractions of $S$. spectabilis showed significant increased in its activity while the hexane and ethyl acetate fractions of $S$. thaipingensis gave higher activity than its aqueous portions. Conclusion - We conclude that plant extracts are potential sources of new anti-ulcer agents.
\end{abstract}

KEYWORDS - Gastrointestinal diseases. Peptic ulcer. Leguminosae. Medicinal plants.

\section{INTRODUCTION}

Peptic ulcer disease is the term used to describe a heterogeneous group of condition with ulcerations. It is characterized by the disruption of the mucosal integrity of the esophagus, stomach, or duodenum ${ }^{(16)}$. As the most common gastrointestinal disturbance, it affects $10 \%-15 \%$ of the population at any one time. Ulcers are primarily caused by an imbalance between some endogenous aggressive and protective factors in the stomach such as acid-pepsin secretion, integrity of the mucosal barrier, mucus secretion, blood flow, cellular regeneration, prostaglandins, and growth factors ${ }^{(12)}$. Several factors are also associated in the occurrence of peptic ulcer including stressful lifestyle, alcohol consumption, use of steroidal and non-steroidal antiinflammatory drugs (NSAIDS), Helicobacter pylori infections, smoking, lower socio-economic status and family history ${ }^{(19)}$. Although ulcer is not a deadly disease, it can lead to more serious complications like gastrointestinal bleeding, perforations, penetration of ulcer into adjacent organs and gastric outlet obstruc$\operatorname{tion}^{(9)}$. Medications are used to relieve the pain, heal ulcerations and delay recurrence of ulcerations. These include antibiotics ${ }^{(33)}$, antacids and proton pump inhibitors $^{(30)}$. Several drugs are available in the market for gastric ulcer therapy; however, most of these drugs are associated with unwanted side effects ${ }^{(23)}$.
In this context, this research aims to evaluate the anti-ulcer properties of medicinal plants. Several researches have confirmed the efficacy of medicinal plants for the treatment of peptic ulcer disease. The observed activity is these plants is attributed with the presence of flavonoids, alkaloids, terpenoids, tannins, saponins, and phenolic acids ${ }^{(4,10,15,21)}$. Extracts of Wilbrandia ebracteata ${ }^{(6)}$, Eruca sativa ${ }^{(2)}$, Toona ciliata Roemer $^{(18)}$, Calligonum somosum ${ }^{(17)}$, Voacanga Africana $^{(26)}$ and Pedalium murex $^{(3)}$ have shown antiulcer activity. An alkaloid from the fruit of Voacanga africana and a protoberberine-type alkaloid from the bark of Enantia chlorantha were found to prevent ulcers ${ }^{(27,28)}$. An alkaloid extract and 2-phenylquinoline from Galipea longiflora Krause have also shown gastroprotective effects ${ }^{(34)}$. Bauhinia purpurea, which belongs to the Leguminosae family, has been shown to inhibit aspirin-induced and ethanol-induced ulcers in mice ${ }^{(29)}$. In this study, other species belonging to the same family were evaluated for their anti-ulcer activity.

\section{METHODS}

\section{Plant Material}

Fresh leaves of Intsia bijuga, Cynometra ramiflora, Tamarindus indica, Cassia javanica, Cassia fistula, Bauhini purpurea, Senna spectabilis, Senna siamea and Saraca thaipingensis were collected from the Univer-

Declared conflict of interest of all authors: none

${ }^{1}$ Natural Sciences Research Institute, University of the Philippines, Diliman, Quezon City $1101 ;{ }^{2}$ Institute of Chemistry, College of Science, University of the Philippines, Diliman, Quezon City 1101

Correspondence: Christine L. Chichioco-Hernandez. Email: cchernandez@upd.edu.ph 
sity of the Philippines, Diliman Campus and submitted to the Dr. Jose Vera Santos Herbarium, Institute of Biology, University of the Philippines, Diliman for authentication. Voucher specimen for each plant were also deposited.

\section{Extraction and solvent partitioning}

The plant samples were washed with running water and air-dried. The dried samples were homogenized for overnight soaking in methanol. The resulting extracts were filtered and concentrated in vacuo using a rotary evaporator at $40^{\circ} \mathrm{C}$. The methanol fractions were partitioned between hexane and water. The resulting aqueous layer was further extracted with ethyl acetate. The hexane and ethyl acetate portions were also concentrated in vacuo.

\section{Phytochemical analysis}

The phytochemical screening methods used were based on Harborne ${ }^{(13)}$ and Edeoga ${ }^{(8)}$. Qualitative test for terpenoids, saponins, tannins, flavonoids, steroids, phenolic compounds, alkaloids and cardiac glycosides were performed.

\section{Bioassay}

\section{1) Animals}

The mice used in the assay were 6-8 weeks old, Swiss Albino mice (ICR strain) purchased from the Food and Drug Administration (FDA) Philippines, Department of Health, Alabang, Muntinlupa City. The animals were acclimated for at least one week in standard cages. The mice were fed with commercial pellets with free access to purified drinking water ad libitum, standard conditions of $12 \mathrm{~h}: 12 \mathrm{~h}$ light/dark cycle, and temperature $\left(23^{\circ} \mathrm{C}-25^{\circ} \mathrm{C}\right)$. The protocol used for the anti-ulcerogenic assay was approved by the College of Science Animal Care and Use Committee (CSACUC) of the University of the Philippines Diliman with assigned protocol number IC 2011-06.

\section{2) $\mathrm{HCl} /$ Ethanol-induced ulcer assay}

The anti-ulcerogenic assay was adapted from the method of Schmeda-Hirschmann ${ }^{(22)}$ with slight modifications. A total of 65 mice were randomly distributed into thirteen treatment groups with 5 mice for the initial assay. Mice weighing $26 \pm 5 \mathrm{~g}$ were deprived of food 24 hours prior to the experiment. Group 1 was given solvent solution with $5 \%$ Tween $80,10 \%$ DMSO and $85 \%$ distilled water. Group 2 was given $\mathrm{HCL} / \mathrm{EtOH}$ only. Group 3 was administered with Sucralfate. Groups 4-12 were treated with the plant samples. Group 13 did not receive any treatment. The plant samples, positive control, and solvent control were orally administered to the mice. The plant extracts were given at a dose of $1000 \mathrm{mg} / \mathrm{kg}$, $0.2 \mathrm{~mL} / 20 \mathrm{~g}$ body weight; Sucralfate at a dose of $200 \mathrm{mg} / \mathrm{kg}$, $0.2 \mathrm{~mL} / 20 \mathrm{~g}$ body weight; and $0.3 \mathrm{M} \mathrm{HCl} / 60 \% \mathrm{EtOH}$.

After an hour, the mice were given $0.2 \mathrm{~mL} / 20 \mathrm{~g}$ b.w. of 0.3 $\mathrm{M} \mathrm{HCl} / 60 \% \mathrm{EtOH}$ solution to induce ulceration. The mice were sacrificed by cervical dislocation an hour after the induction of ulceration. The stomachs were excised and inflated by injecting with $0.9 \%$ normal saline solution. The excised stomachs were fixed with $10 \%$ phosphate buffered solution for at least 15 minutes, and opened along the greater curvature to expose the gastric mucosal layer. Hemorrhagic lesions in the mucosal membrane of the glandular region were observed under a dissecting microscope and were manually scored. Scoring of ulcerations was patterned after Adensawo et al. ${ }^{(1)}$. Normal gastric mucosa was scored as 0 , pinpoint ulcers were scored 0.5 , one or two small hemorrhages were given 1.0 and ulcers with diameters greater than $3 \mathrm{~mm}$ or characterized by heavy bleeding were given a score 2.0.

Fifty mice were randomly distributed into ten treatment groups for the second assay. Groups 1-3 were given similar treatments as in the initial assay. Groups 4-9 were given plant extracts. Group 10 did not receive any treatment. Similar concentrations were used as in the first assay.

The ulcer index (UI) was obtained from the sum of the scores of all lesions for each stomach, and the mean ulcer index $\left(\mathrm{UI}_{\text {MEAN }}\right)$ was calculated for each group. Percent ulcer inhibition of the samples was determined using the following equation:

$$
\% \text { ulcer inhibition }=\frac{\left(\mathrm{UI}_{\text {MEAN }} \text { control- } \mathrm{UI}_{\text {MEAN }} \text { sample }\right)}{\mathrm{UI}_{\text {MEAN }} \text { control }} \times 100 \%
$$

\section{Data analysis}

Data were analyzed by one-way analysis of variance (ANOVA) followed by Dunnet's multiple comparison test using SPSS version 16.0 to determine statistical differences between the treated and the control group. The level of signficance was set at $P<0.05$

\section{RESULTS}

The methanol extracts of I. bijuga, C. ramiflora, T. indica, C. javanica, C. fistula, B. purpurea, S. spectabilis, S. siamea and $S$. thaipingensis were evaluated for their gastroprotective action against $\mathrm{HCl}-\mathrm{EtOH}$-induced ulcer. Figure 1 shows the

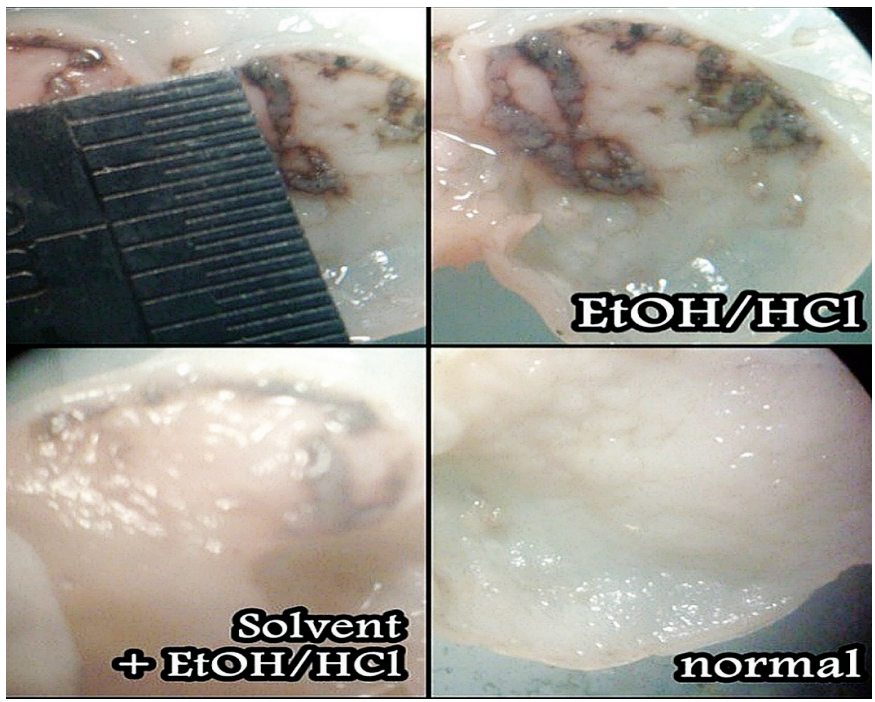

FIGURE 1. Ulcerations caused by $\mathrm{HCl} / \mathrm{EtOH}$ in mice. 
ulcerations resulting from $\mathrm{HCl}-\mathrm{EtOH}$ treatment. Varying gastroprotective activities of the extracts are shown in Table 1 . The anti-ulcer activity of the extracts may be due to the phytochemicals they contain. The phytochemical profiles of all plant samples were determined and the results of the tests are shown in Table 2. The methanol extracts of $S$. spectabilis and $S$. thaipingensis were partitioned with hexane and ethyl acetate to further examine their high activity. The increase in gastroprotective activities of the hexane, ethyl acetate, aqueous extracts are shown in Table 3.

TABLE 1. Gastroprotective activity of $\mathrm{MeOH}$ samples in $\mathrm{HCl} / \mathrm{EtOH}$-induced ulcer in mice

\begin{tabular}{lcc}
\hline Treatment & Ulcer Index (mean \pm SEM) & Ulcer Inhibition(\%) \\
\hline Solvent & $6.000 \pm 0.423$ \\
HCl/EtOH only & $5.143 \pm 0.688$ \\
Sucralfate & $1.000_{ \pm} 0.244^{*}$ & 83.3 \\
Intsia bijuga (Colebr.) O.K. & $2.500_{ \pm} 0.775 *$ & 58.3 \\
Cynometra ramiflora L. Var. ramiflora & $5.167 \pm 0.989$ & 13.9 \\
Tamarindus indicus L. & $2.417 \pm 0.800^{*}$ & 59.7 \\
Cassia javanica L. ssp. Nodosa (Buch.-Ham. Ex. Roxb)K. \& S.S. Larsen & $4.167 \pm 1.123$ & 30.6 \\
Cassia fistula L. & $4.417 \pm 0.889$ & 26.4 \\
Baubinia purpurea L. & $3.500 \pm 1.084$ & 41.7 \\
Senna spectabilis (DC.) Irwin \& Barneby & $2.083 \pm 0.970 *$ & 65.3 \\
Senna siamea (Lam.) Irwin \& Barneby & $3.917 \pm 0.908$ & 34.7 \\
Saraca thaipingensis Cantley ex Prain & $1.200 \pm 0.464^{*}$ & 80.0 \\
Normal (no treatment) & $0.000_{ \pm} 0.000^{*}$ & \\
\hline
\end{tabular}

* Samples statisticaly different compared to the solvent control $(\mathrm{P}<0.05)$

TABLE 2. Phytochemical analysis of plant species in the Leguminosae family

\begin{tabular}{|c|c|c|c|c|c|c|c|c|}
\hline Plant species & Flavonoids & Tannins & Terpenoid & Alkaloid & $\begin{array}{l}\text { Cardiac } \\
\text { Glycoside } \\
\end{array}$ & Phenolics & Saponin & Steroids \\
\hline Intsia bijuga (Colebr.) O.K. & + & + & + & + & + & + & + & + \\
\hline Cynometra ramiflora $\mathrm{L}$. Var. ramiflora & + & + & - & + & - & + & + & + \\
\hline Tamarindus indicus $\mathrm{L}$. & + & + & - & + & + & + & + & - \\
\hline $\begin{array}{l}\text { Cassia javanica L. ssp. Nodosa (Buch.-Ham. Ex. } \\
\text { Roxb) K. \& S.S. Larsen }\end{array}$ & + & - & + & + & + & + & + & - \\
\hline Cassia fistula $\mathrm{L}$. & + & - & + & - & - & - & + & - \\
\hline Baubinia purpurea L. & + & + & - & + & + & - & + & + \\
\hline Senna spectabilis (DC.) Irwin \& Barneby & + & + & - & + & - & + & + & + \\
\hline Senna siamea (Lam.) Irwin \& Barneby & + & + & - & + & + & + & + & + \\
\hline Saraca thaipingensis Cantley ex Prain & + & + & + & - & + & + & + & + \\
\hline
\end{tabular}

TABLE 3. Gastroprotective activity of $S$. spectabilis and $S$. thaipingensis fractions in $\mathrm{HCl} / \mathrm{EtOH}$-induced ulcer in mice

\begin{tabular}{lccc}
\hline & Treatment & Ulcer Index $\left(\right.$ mean ${ }_{ \pm}$SEM) & Ulcer Inhibition $(\%)$ \\
\hline Solvent & & $6.562 \pm 0.8097$ & $5.000 \pm 0.8062$ \\
HCl/EtOH only & & $3.143 \pm 0.7846 *$ & 52.1 \\
Sucralfate & Aqueous extract & $1.357 \pm 0.7377 *$ & 79.3 \\
S. spectabilis & Ethyl acetate extract & $1.857 \pm 1.0160 *$ & 71.7 \\
& Hexane extract & $5.833 \pm 0.7601$ & 11.1 \\
S. thaipingensis & Aqueous extract & $5.000 \pm 0.5323$ & 23.8 \\
& Ethyl acetate extract & $2.429 \pm 0.7975 *$ & 63.0 \\
& Hexane extract & $2.429 \pm 0.8690 *$ & 63.0 \\
Normal (no treatment) & & $0.429 \pm 0.2974 *$ & \\
\hline
\end{tabular}

* Samples statisticaly different compared to the solvent control $(P<0.05)$ 


\section{DISCUSSION}

All extracts were active and showed varying degrees of gastroprotection. It is possible that plants belonging to the Leguminosae family are able to inhibit ulcers. I. bijuga, $T$. indica, S. spectabilis and $S$. thaipingensis showed higher than $50 \%$ inhibition. S. thaipingensis showed the highest activity at $80 \%$ which is comparable with the activity of the positive control sucralfate at $83 \%$ inhibition. These plants showed significant anti-ulcer action against $\mathrm{HCl}-\mathrm{EtOH}$ ulcerogen. Alcohol consumption is a contributor to gastric ulceration ${ }^{(1)}$ and excessive consumption increases the risk for gastric mucosal damage. Ethanol causes gastric ulcers by lowering protective factors in the gastric mucosa ${ }^{(5)}$. Ethanol-induced ulcers in mice are characterized by heavy bleeding since it can cause immediate stasis in the blood flow ${ }^{(20)}$. It is possible that the extracts contain compounds that can enhance protective factors and restore gastric blood circulation.

Phytochemicals refer to a wide-variety of compounds produced by plants with no nutritive value. They are promoted for their protective and disease-preventive properties according to the American Cancer Society website. Stilbenes and flavonoids were isolated from the heartwood of I. bijuga $a^{(14)}$. T. indica showed 59.6\% ulcer inhibition. The results supported its used for gastrointestinal disorders in India ${ }^{(7,25)}$.
S. spectabilis activity showed significant increased inhibition for its ethyl acetate and aqueous fractions at $71.7 \%$ and $79.3 \%$, respectively. Result showed that hexane and ethyl acetate extracts of $S$. thaipingensis exhibited significant bioactivity, both at $63 \%$. No significant activity was observed for the aqueous extract. The flowers of $S$. spectabilis previously yielded three new bioactive piperidine alkaloids ${ }^{(31)}$. Its leaves, roots and stems also gave different alkaloids ${ }^{24}$ 32). Phytochemical screening of the methanolic extract of $S$. thaipingensis showed the presence of flavonoids, terpenoids, tannins, saponins, and phenolic acids which are known to have anti-ulcer activities ${ }^{(4,19,21)}$. The bioactivity of the extracts could be attributed to these secondary metabolites.

\section{CONCLUSION}

The different plant extracts gave varying degrees of anti-ulcer activity and could be a potential source of new anti-ulcer agents. Further studies are underway to identify these compounds.

\section{ACKNOWLEDGEMENT}

This project was funded by the Natural Sciences Research Institute of the University of the Philippines Diliman.

Paguigan ND, Castillo DHB, Chichioco-Hernandez CL. Atividade anti-úlcera de plantas leguminosas. Arq Gastroenterol. 2014,51(1):64-8.

RESUMO - Contexto - A úlcera é o distúrbio gastrointestinal mais comum que resulta de uma inadequada defesa da mucosa gástrica. Vários medicamentos estão disponíveis no mercado para tratar a doença, no entanto, estas drogas podem se associar a efeitos colaterais desnecessários. Objetivos Pesquisas anteriores confirmaram a eficácia de extratos de plantas como possível tratamento da doença. Esta pesquisa teve como objetivo avaliar as propriedades anti-úlcera de plantas medicinais. Métodos - Extratos alcoólicos das folhas da Intsia bijuga, Cynometra ramiflora, Tamarindus indica, Cassia javanica, Cassia fistula, Bauhini purpurea, Senna spectabilis, Senna siamea e Saraca thaipingensis foram avaliados pela sua atividade anti-úlcera usando o HCl-etanol como ulcerogênico. Resultados - Todos os extratos apresentaram atividade inibitória; I.bijuga, T. Índica, S. spectabilis e S. thaipingensis mostraram mais de $50 \%$ de inibição. A S. thaipingensis mostrou a maior atividade, atingindo $80 \%$. S. spectabilis e S. thaipingensis foram divididos mais em hexano, acetato de etila e frações aquosas. As frações aquosas e acetato de etila de S. spectabilis mostraram aumento significativo em sua atividade, enquanto que as frações hexano e acetato de etila de $S$. thaipingensis resultaram em maior atividade do que em partes aquosas. Conclusão - Pode-se concluir que os extratos vegetais são fontes potenciais de novos agentes anti-úlcera.

DESCRITORES - Gastroenteropatias. Úlcera péptica. Leguminosas. Plantas medicinais. 


\section{REFERENCES}

1. Adensawo JK, Fadare OO, Ige OO, Odusanya OO, Onasanwo SA, Olaleye SB, Raji Y. Antiulcer Activity of Methanolic Extract of Bryophyllum pinnatum in Rats. J Biol Sci. 2007;7:409-12.

2. Alqasoumi S, Al-Sohaibani M, Al-Howiriny T, Al-Yahya M, Rafatullah S. Rocket "Eruca sativa": a salad herb with potential gastric anti-ulcer activity. World J Gastroenterol. 2009;28:1958-65.

3. Banji D, Singh J, Banji OJ. Scrutinizing the aqueous extract of leaves of pedalium murex for the antiulcer activity in rats. Pak J Pharm Sci. 2010; 23:295-9.

4. Borrelli F, Izzo AA. The Plant Kingdom as a Source of Anti-ulcer. Phytother Res. 2000;14:581-91.

5. Choi E, Hwang H, Kim I, Nam T. Protective effects of a polysaccharide from 525 Hizikia fusiformis against ethanol toxicity in rats. Food Chem Toxicol. 2009;526:134-9.

6. Coelho RG, Gonzalez FG, Sannomiya M, Di Stasi LC, Vilegas W. Gastric anti-ulcer activity of leaf fractions obtained of polar extract from Wilbrandia ebracteata in mice. Nat Prod Res. 2009;23:51-9.

7. Dey A, De JN. Ethnobotanical survey of Purulia district, West Bengal, India for medicinal plants used against gastrointestinaldisorders. J Ethnopharmacol. 2012;143:68-80.

8. Edeoga HO, Okwu DE, Mbaebie. Phytochemical Constituents of Some Nigerian Medicinal Plants. Afr J Biotechnol. 2005;4:685-8.

9. Everheart JE. Digestive Diseases in the United States. United States of America: Diane Publishing; 1994. p. 357-408.

10. Falcão HDS, Leite JA, Barbosa-Filho JM, Athayde-Filho PF, Chaves MCP, Ferreira AL, de Almeida ABA, Souza-Brito ARM, Diniz MFFM, Batista LM. Gastric and Duodenal Antiulcer Activity of Alkaloids: A Review. Molecules. 2008:13:3198-223.

11. Franke A, Teyssen S, Singer MV. Alcohol-related diseases of the esophagus and stomach. Digest Dis Sci. 2005;23:204-13.

12. Freitas CS, Baggio CH, Finau J, Anginoni M, Pizzolatti MG, Santos ARS, Marquez MCA. Inhibition of $\mathrm{H}+/ \mathrm{K}+$ ATPase in the gastroprotective effect of Baccharis illinita DC. J Pharm Pharmacol. 2008;60:1105-10.

13. Harborne JB. Phytochemical Methods: A Guide to Modern Techniques of Plant Analysis. 2. ed. United States of America: Chapman and Hall. 1984.

14. Hillis WE, Yazaki Y. Polyphenols of Intsia heartwoods. Phytochemistry. 1973;12:2491-5.

15. Hosseinzadeh H, Karimi GR, Ameri M. Effects of Anethum graveolens L. seed extracts on experimental gastric irritation models in mice. BMC Pharmacology. 2002;2:21.

16. Kumar A, Dewan B, Rama T. Evaluation of anti-ulcerogenic properties from the root of Flemingia strobilifera. J Basic Clin Pharm. 2011;2(1).

17. Liu XM, Zakaria MN, Islam MW, Radhakrishnan R, Ismail A, Chen HB, Chan $\mathrm{K}$, Al-Attas A. Anti-inflammatory and anti-ulcer activity of Calligonum comosum in rats. Fitoterapia. 2001;72:487-91.
18. Malairajan P, Gopalakrishnan G, Narasimhan S, Veni KJ, Kavimani S. Anti-ulcer activity of crude alcoholic extract of Toona ciliata Roemer (heart wood). J Ethnopharmacol. 2007;21:348-51.

19. Mota KSdL, Dias GEN, Pinto MEF, Luiz-Ferreira A, Souza-Brito ARM, Hiruma-Lima CA, Barbosa-Filho JM, Batista LM. Flavonoids with Gastroprotective Activity. Molecules. 2009;14:979-1012.

20. Muralidharan P, Srikanth J. Antiulcer Activity of Morinda Citrifolia Linn Fruit Extract. J Sci Res. 2009;1:345-52.

21. Patil PH, Patil JY, Mahale JN, Patel JB, Surana SJ. Evaluation of antiulcer activity of the terpenoid fraction from the leaves of Thespesia populnea (L) (Malvaceae) in albino rats. Res J Pharm Bio Che Sci. 2010;4:495-513.

22. Schmeda-Hirschmann G, Theoduloz C, Sanchez M, Razmilic I, Yanez T, Rodriguez JA. Gastroprotective and ulcer-healing activity of oleonolic acid derivatives: In vitro-in vivo relationships. Life Sci. 2006;79:1349-56.

23. Shirode D, Patel T, Pal Roy S, Jyothi TM, Rajendra SV, Prabhu K, Setty SR Anti-ulcer properties of $70 \%$ ethanolic extract of leaves of Albizzia lebbeck. Phcog Mag. 2008;4:228-31.

24. Silva FDO, Silva MGV, Feng D, De Freitas RM. Evaluation of central nervous system effects of iso-6-cassine isolated from Senna spectabilis var. excelsa (Schrad) in mice. Fitoterapia. 2011;82:255-9.

25. Singh A, Singh PK. An ethnobotanical study of medicinal plants in Chandauli District of Uttar Pradesh, India. J Ethnopharmacol. 2009;121:324-9.

26. Tan PV, Nyasse B. Anti-ulcer compound from Voacanga africana with possible histamine $\mathrm{H} 2$ receptor blocking activity. Phytomedicine. 2000;7:509-15.

27. Tan PV, Nyasse B, Dimo T, Wafo P, Akahkuh BT. Synergistic and potentiating effects of ranitidine and two new anti-ulcer compounds from Enantia chlorantha and Voacanga africana in experimental animal models. Pharmazie. 2002;57:409-12.

28. Tan PV, Nyasse B, Enow-Orock GE, Wafo P, Forcha EA. Prophylactic and healing properties of a new anti-ulcer compound from Enantia chlorantha in rats. Phytomedicine. 2000;7:291-6.

29. Tarin JMK, Chichioco-Hernandez C. Gastroprotective effects of Bauhinia purpurea, Dolichos lablab and Vitex parviflora. Lat Am J Pharm. 2011;30:558-62.

30. Tepperman BL, Jacobson ED. Circulatory factors in gastric mucosal defense and repair. In Physiology of the Gastrointestinal Tract, Johnson LR (ed.). Raven Press: New York. 1994.

31. Viegas C, Bolzani V, Furlan M, Barreiro E, Young MCM, Tomazela D, Eberlin MN. Further bioactive piperidine alkaloids from the flowers and green fruits of Cassia spectabilis. J Nat Prod. 2004;67:908-10.

32. Viegas C, Bolzani VS, Pimentel LSB, Castro NG, Cabral RF, Costa RS, Floyd C, Rocha MR, Young MCM, Barreiroa EJ, Fraga CAM. New selective acetylcholinesterase inhibitors designed from natural piperidine alkaloids. Bioorgan Med Chem. 2005;13:4148-90.

33. Yuan Y, Padol IT, Hunt RH. Peptic ulcer today. Nat Clin Pract Gastr. 2006;3:80-9.

34. Zanatta F, Gandolfi RB, Lemos M, Ticona JC, Gimenez A, Clasen BK, Cechinel Filho V, de Andrade SF. Gastroprotective activity of alkaloid extract and 2-phenylquinoline obtained from the bark of Galipea longiflora Krause (Rutaceae). Chem-Biol Interact 2009;15:312-7. 